\title{
Adherence of Serratia marcescens in the pathogenesis of urinary tract infections in diabetic mice
}

\author{
Y. OBANA, K. SHIBATA and T. NISHINO \\ Department of Microbiology, Kyoto Pharmaceutical University, 5 Nakauchi-cho, Misasagi, Yamashina, Kyoto 607. \\ Japan
}

\begin{abstract}
Summary. The adherence of Serratia marcescens to bladder epithelial cells of mice with alloxan-induced diabetes was studied. $S$. marcescens adhered more strongly to the bladder epithelial cells of diabetic mice than to those of normal mice both in vitro and in vivo. The susceptibility of diabetic mice to urinary tract infection may be due to an increased adhesive capacity of bladder epithelial cells.
\end{abstract}

\section{Introduction}

With increased use of broad-spectrum antibiotics, especially third generation cephalosporins, superinfection by relatively antibiotic-resistant opportunist pathogens such as Pseudomonas, Acinetobacter and Serratia spp. has been noted.

Patients with diabetes mellitus have an increased susceptibility to infections. In these patients, the three most common sites of infection are the lung, skin and urinary tract. We have reported previously that diabetic mice were significantly more susceptible to experimental pulmonary infection with Klebsiella pneumoniae and to urinary tract infection with Proteus mirabilis, S. marcescens and Enterobacter cloacae than normal mice; this increased susceptibility was not found with Escherichia coli, $P$. aeruginosa or $A$. calcoaceticus. ${ }^{1,2}$

In the present study, we assessed the effect of alloxan-induced diabetes on experimental $S$. marcescens urinary tract infections in mice. $S$. marcescens is frequently isolated from immunocompetent hosts with complicated urinary tract infection. We also compared the adhesive capacity of these bacteria for bladder epithelial cells obtained from normal and diabetic mice.

\section{Materials and methods}

\section{Bacterial strains}

Ten strains of $S$. marcescens were used. Seven strains were isolated from the urine of patients with urinary tract infections. The source of the other strains was unknown. Cultures used for infection were grown in nutrient broth at $37^{\circ} \mathrm{C}$ for $18 \mathrm{~h}$, diluted with fresh nutrient broth, and used immediately. Bacterial counts at the time of infection were estimated by plate counts on nutrient agar.

\section{Animals}

Slc-ddY female mice weighing 20-22 g were used.

\section{Induction of diabetes}

The method for producing experimental diabetes has been described in detail elsewhere. ${ }^{3}$ Four days after intraperitoneal injection of alloxan monohydrate, $250 \mathrm{mg} / \mathrm{kg}$ body weight, N-Multistic ${ }^{\circledR} \mathrm{SG}$ was used to screen the urine for the presence of glucose. Animals with glycosuria (glucose $>10.0 \mathrm{mg} / \mathrm{ml}$ ) were used in the study.

\section{Urinary tract infection}

Urinary tract infections were induced in normal and diabetic mice. ${ }^{4}$ Water supply was restricted for a $3 \mathrm{~h}$ period and mice were inoculated via the urethra with the 10 strains of $S$. marcescens in a dose volume of $0.05 \mathrm{ml}$. The mice were killed $72 \mathrm{~h}$ after inoculation and the kidneys and bladders were removed aseptically. All organs, with their contents, were homogenised in sterile physiological saline, and serial dilutions were plated on nutrient agar to obtain colony counts.

\section{Bacterial adherence assay}

The numbers of adherent bacteria were determined by the method of Hagberg et al. ${ }^{5}$ with slight modification. Briefly, mouse epithelial cells from the bladder of normal and diabetic mice were obtained by scraping the organ with a wooden spatula. Cells were washed twice and suspended in $0.1 \mathrm{M}$ phosphate-buffered saline (PBS; pH 7.2). The bacteria were grown in nutrient broth for $18 \mathrm{~h}$, harvested by centrifugation, washed and resuspended in PBS. Samples containing $10^{8} \mathrm{cfu}$ of bacteria and $10^{5}$ epithelial cells were prepared. After incubation at $37^{\circ} \mathrm{C}$ for $60 \mathrm{~min}$, samples were washed three times by centrifugation with PBS to eliminate unattached bacteria, and spread on a 
glass microscope slide. After being dried and fixed, the preparation was stained with Giemsa and examined by a bright-field microscopy. Adherence was defined as the mean number of bacteria adhering to 100 epithelial cells. ${ }^{6}$ In the case of $S$. marcescens strain $\mathrm{T}-55$, the adherence assay was performed in the presence and absence of D-mannose $2.5 \% \mathrm{w} / \mathrm{v}$.

\section{Electronmicroscopy}

For the observation of in-vivo adherence of bacteria to bladder lumen surfaces, the bladders of animals infected with $S$. marcescens strain T-55 were removed aseptically and then fixed with glutaraldehyde and osmium tetroxide. Samples were examined by scanning electronmicroscopy. The fimbriation of $S$. marcescens strain T-55 grown in nutrient broth for $18 \mathrm{~h}$ at $37^{\circ} \mathrm{C}$ was examined by a negative staining technique and transmission electronmicroscopy.

\section{Results}

\section{Urinary tract infection}

Tables I and II show that diabetic mice were significantly more susceptible to experimental urinary tract infections than normal mice with all the $S$. marcescens strains tested.

\section{Bacterial adherence}

Table III shows the results with the six $S$. marcescens strains tested: with the exception of $S$. marcescens strain T-52, five strains showed greater adherence to the bladder epithelial cells of diabetic mice than to those of normal mice. The mean numbers of bacteria adhering to bladder epithelial cells of normal and diabetic mice were 7.08 SD $2 \cdot 10$ and 12.90 SD $2 \cdot 78$ per cell, respectively. D-Mannose partially inhibited

Table I. Bacterial viable counts in the kidneys of normal and diabetic mice inoculated urethrally with $S$. marcescens

\begin{tabular}{|c|c|c|c|c|c|}
\hline \multirow[t]{2}{*}{ Strain no. } & \multirow[t]{2}{*}{ Source } & \multirow{2}{*}{$\begin{array}{c}\text { Inoculum } \\
\left(\log _{10} \mathrm{cfu} / \text { mouse }\right)\end{array}$} & \multicolumn{2}{|c|}{$\begin{array}{l}\text { Mean (SD) bacterial viable } \\
\text { counts* }\left(\log _{10} \mathrm{cfu}\right), 72 \mathrm{~h} \text { after in- } \\
\text { fection, in the kidneys of }\end{array}$} & \multirow[b]{2}{*}{$\mathrm{p}$ value $\dagger$} \\
\hline & & & normal mice & diabetic mice & \\
\hline $\mathrm{K}-1$ & UTI & $2 \cdot 6$ & $4 \cdot 2(2 \cdot 1)$ & $6 \cdot 7(1 \cdot 2)$ & $<0.01$ \\
\hline $\mathrm{K}-3$ & UTI & $3 \cdot 7$ & $4.8(0.6)$ & $7 \cdot 1(0 \cdot 3)$ & $<0.01$ \\
\hline \multirow[t]{2}{*}{$\mathrm{K}-4$} & UTI & $3 \cdot 0$ & $4 \cdot 2(0 \cdot 7)$ & $7 \cdot 2(0 \cdot 5)$ & $<0.01$ \\
\hline & & $2 \cdot 0$ & $4 \cdot 0(1 \cdot 2)$ & $6.8(0.3)$ & $<0.01$ \\
\hline \multirow[t]{2}{*}{$\mathrm{K}-12$} & UTI & $3 \cdot 0$ & $4.4(0.9)$ & $7 \cdot 1(0 \cdot 2)$ & $<0.01$ \\
\hline & & $2 \cdot 0$ & $3.4(0.7)$ & $6.8(0.5)$ & $<0.01$ \\
\hline \multirow[t]{2}{*}{$\mathrm{T}-8$} & UTI & $2 \cdot 8$ & $5 \cdot 6(1 \cdot 2)$ & $7.3(0.7)$ & $<0.05$ \\
\hline & & 1.8 & $3 \cdot 2(1 \cdot 6)$ & $6.9(1.4)$ & $<0.01$ \\
\hline \multirow[t]{2}{*}{$\mathrm{T}-11$} & Unknown & $2 \cdot 9$ & $5.4(1.6)$ & $6.9(0.5)$ & $<0.05$ \\
\hline & & 1.9 & $4 \cdot 4(1 \cdot 1)$ & $6 \cdot 5(1 \cdot 2)$ & $<0.01$ \\
\hline \multirow[t]{2}{*}{$\mathrm{T}-12$} & UTI & 3.0 & $4 \cdot 6(1 \cdot 0)$ & $6.2(0.9)$ & $<0.01$ \\
\hline & & $2 \cdot 0$ & $3.4(0.8)$ & $5.6(0 \cdot 6)$ & $<0.01$ \\
\hline $\mathrm{T}-51$ & Unknown & $3 \cdot 1$ & $3 \cdot 2(1 \cdot 6)$ & $6 \cdot 7(1 \cdot 3)$ & $<0.01$ \\
\hline \multirow[t]{2}{*}{$\mathrm{T}-52$} & UTI & $3 \cdot 2$ & $4 \cdot 7(1 \cdot 3)$ & $7 \cdot 3(0.4)$ & $<0.01$ \\
\hline & & $2 \cdot 2$ & $4 \cdot 3(1 \cdot 5)$ & $7.0(0 \cdot 2)$ & $<0.01$ \\
\hline $\mathrm{T}-55$ & Unknown & $2 \cdot 9$ & $4 \cdot 2(1 \cdot 0)$ & $7 \cdot 7(0.3)$ & $<0.01$ \\
\hline
\end{tabular}

*Each value represents the mean (SD) of five mice.

†Student's $t$ test.

UTI, urinary tract infection.

Table II. Bacterial viable counts in the kidneys and bladders of normal and diabetic mice inoculated urethrally with $S$. marcescens strain T-55

\begin{tabular}{|c|c|c|c|c|c|c|}
\hline \multirow{3}{*}{$\begin{array}{c}\text { Dose of viable } \\
\text { organisms } \\
\left(\log _{10} \text { cfu/mouse }\right)\end{array}$} & \multicolumn{6}{|c|}{ Mean (SD) viable count $\left(\log _{10} \mathrm{cfu}\right)^{*}$ of bacteria, $72 \mathrm{~h}$ after infection in the } \\
\hline & \multicolumn{3}{|c|}{ kidneys of } & \multicolumn{3}{|c|}{ bladders of } \\
\hline & normal mice & diabetic mice & $\mathrm{p}$ value $\dagger$ & normal mice & diabetic mice & $\mathrm{p}$ value \\
\hline $3 \cdot 3$ & $4 \cdot 3(1 \cdot 5)$ & $7 \cdot 0(0 \cdot 5)$ & $<0.01$ & $4 \cdot 0(1 \cdot 3)$ & $7 \cdot 4(0 \cdot 4)$ & $<0.01$ \\
\hline $2 \cdot 3$ & $3.7(1 \cdot 1)$ & $6.3(0.7)$ & $<0.01$ & $3.5(0.4)$ & $6.7(0.7)$ & $<0.01$ \\
\hline
\end{tabular}

*Each value represents the mean (SD) of five mice. 
Table III. Adherence of $S$. marcescens strains to uroepithelial cells from normal and diabetic mice

\begin{tabular}{|c|c|c|c|c|c|c|}
\hline \multirow{3}{*}{$\begin{array}{l}\text { Strain } \\
\text { no. }\end{array}$} & \multirow{3}{*}{ Source } & \multicolumn{4}{|c|}{$\begin{array}{l}\text { Bacterial viable counts/100 uro- } \\
\text { epithelial cells from }\end{array}$} & \multirow{3}{*}{ p value* } \\
\hline & & \multicolumn{2}{|c|}{ normal mice } & \multicolumn{2}{|c|}{ diabetic mice } & \\
\hline & & Exp 1 & Exp 2 & $\operatorname{Exp} 1$ & Exp 2 & \\
\hline K-4 & UTI & 665 & 570 & 1026 & 980 & \\
\hline $\mathbf{K}-12$ & UTI & 858 & 952 & 1705 & 1660 & \\
\hline $\mathrm{T}-11$ & Unknown & 813 & 872 & 1343 & 1543 & \\
\hline $\mathrm{T}-12$ & UTI & 410 & 386 & 1340 & 1109 & \\
\hline $\mathrm{T}-52$ & UTI & 933 & 893 & 993 & 937 & \\
\hline $\mathrm{T}-55$ & Unknown & 565 & 580 & 1306 & 1540 & \\
\hline \multicolumn{2}{|c|}{ Mean (SD) $\dagger$} & \multicolumn{2}{|c|}{$7 \cdot 08(2 \cdot 10)$} & \multicolumn{2}{|c|}{$12 \cdot 90(2 \cdot 78)$} & $<0.01$ \\
\hline
\end{tabular}

UTI, urinary tract infection.

*Student's $t$ test.

$\dagger$ Each value represents the mean count per uroepithelial cell of two experiments.

adherence of $S$. marcescens strain T-55 to the epithelial cells of both normal and diabetic mice (table IV).

\section{Electronmicroscopy}

$S$. marcescens strain T-55 grown in nutrient broth possessed numerous fine fimbriae (fig. 1). To examine in-vivo adherence, the bladder lumen surfaces were observed by scanning electronmicroscopy. In alloxantreated mice, bladder lumen surfaces were morpho-
Table IV. Effect of D-mannose $2.5 \%$ on adherence of $S$. marcescens strain $\mathrm{T}-55$ to uroepithelial cells from normal and diabetic mice

\begin{tabular}{|c|c|c|}
\hline \multirow{2}{*}{ Treatment } & \multicolumn{2}{|c|}{$\begin{array}{l}\text { Bacterial viable counts } / 200 \text { uroepithe- } \\
\text { lial cells* from }\end{array}$} \\
\hline & normal mice & diabetic mice \\
\hline $\begin{array}{l}\text { None } \\
\text { D-Mannose }\end{array}$ & $\begin{array}{l}1200 \\
479(60 \cdot 0 \%) \dagger\end{array}$ & $\begin{array}{l}2421 \\
1450(40 \cdot 1 \%)+\end{array}$ \\
\hline
\end{tabular}

*One hundred randomly selected cells were examined in each of two experiments.

†Percentage inhibition of attachment.

logically similar to those of the control specimens (fig. 2). In diabetic mice, numerous rod-shaped bacteria were seen in the infected bladders $48 \mathrm{~h}$ after inoculation. These organisms adhered preferentially to the regions adjacent to lateral cell borders. Fibrin-like strands were seen connecting bacterial cells to each other and to epithelial surfaces. The cell surfaces appeared roughened and irregular (fig. 3); $72 \mathrm{~h}$ after bacterial inoculation, eroded cell surfaces were apparent in areas surrounding the adherent bacteria. The intercellular junction was dilated (fig. 4). Bacteria were not observed to adhere to the bladder lumen surfaces of normal mice inoculated with $10^{3}$ cells of $S$. marcescens strain T-55 per mouse (fig. 5). Histological examinations confirmed these electronmicroscopic observations (data not shown).

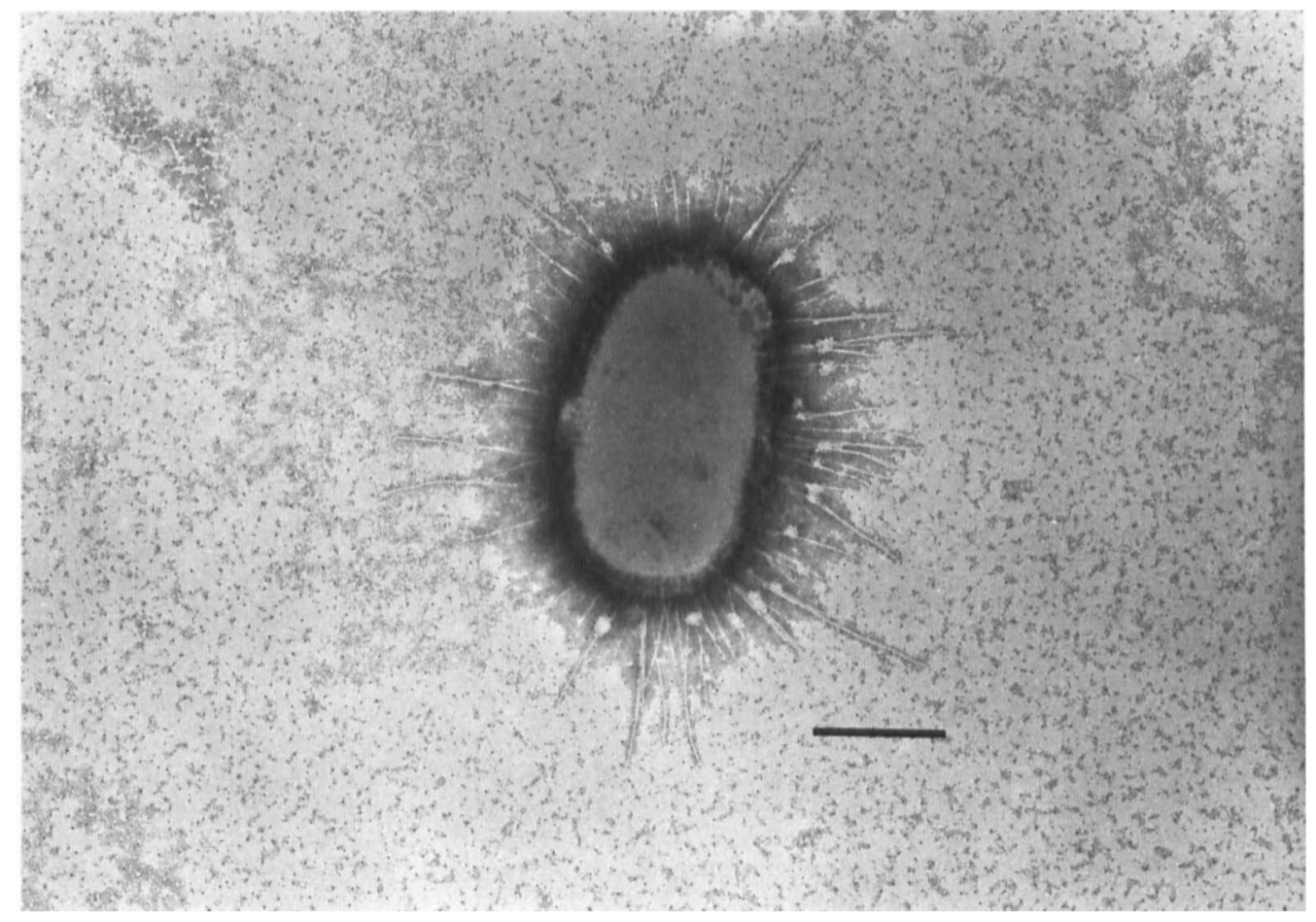

Fig. 1. Negatively stained electronmicrograph of $S$. marcescens $T-55$ fimbriae. Two morphologically different fimbriae protrude from the cell surface. Bar $=0.5 \mu \mathrm{m}$. 


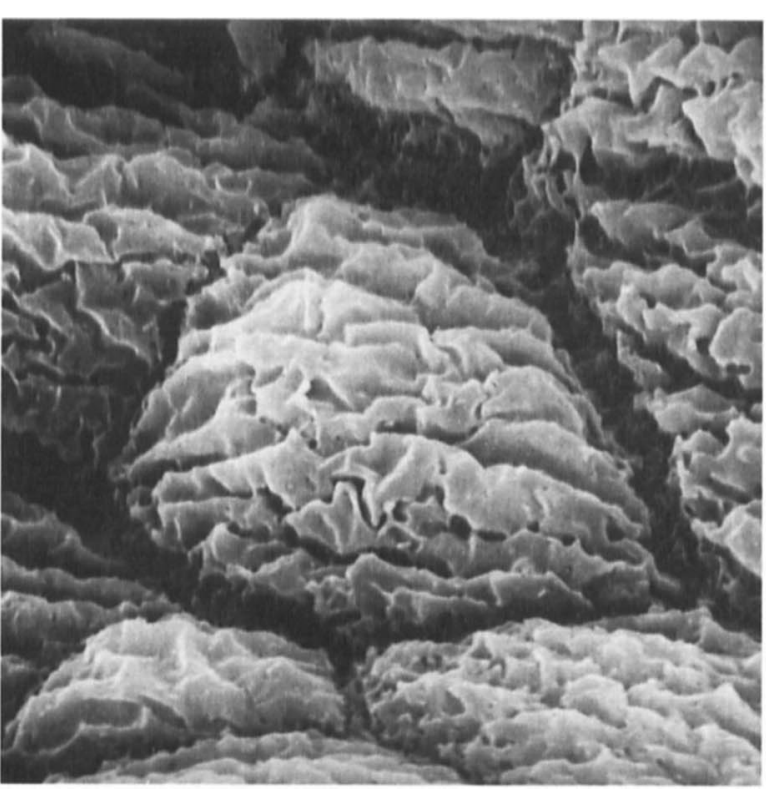

Fig. 2. Scanning electronmicrograph of the urothelium of untreated diabetic mouse showing the polygonal cells of the epithelium $(\times 4000)$.

\section{Discussion}

The adherence of bacteria to mucosal surfaces is an important step in the pathogenesis of most infections in man and animals. Hagberg et al. ${ }^{5}$ have reported that the expression of urinary tract infections as symptomatic or asymptomatic may be related to the ability of the bacteria to adhere to the mucosal surfaces of the urinary tract. The attachment of bacteria to bladder epithelial cells and growth in the urine are probably essential preliminaries to bladder infection.

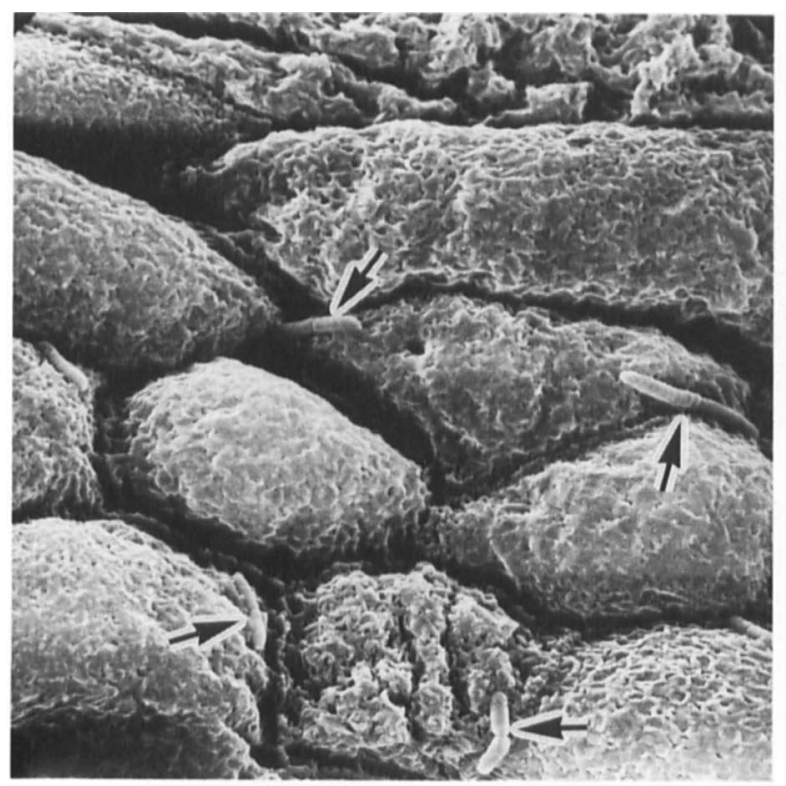

Fig. 4. Scanning electronmicrograph showing the adherence of $S$. marcescens $\mathrm{T}-55$ (arrows) and the damaged urothelium of diabetic mouse, $72 \mathrm{~h}$ after infection. Advanced accumulation of fibrin-like strands, irregularly widened intercellular spaces and various disturbed epithelial surfaces are seen $(\times 4000)$.

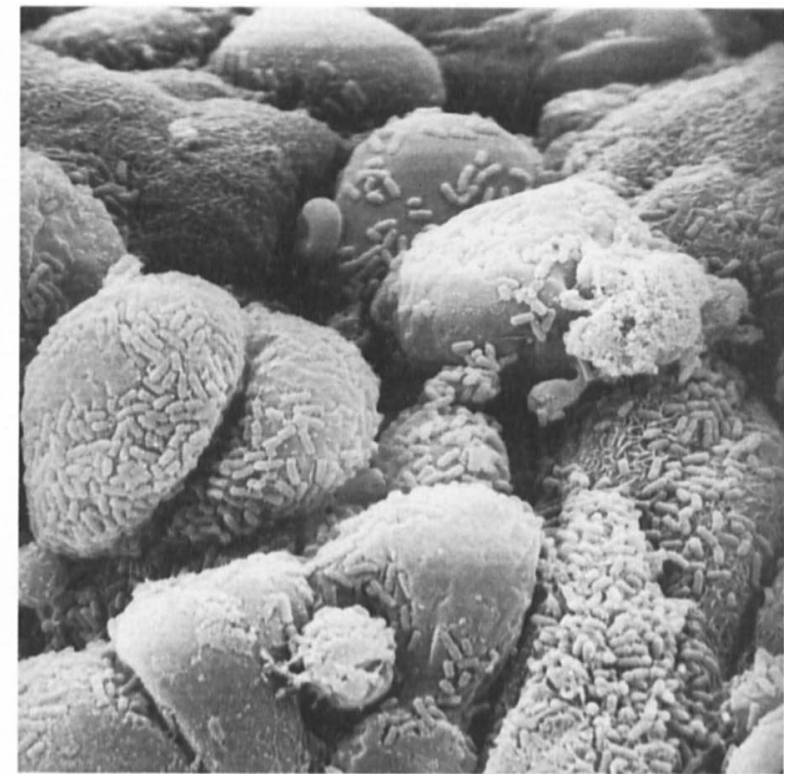

Fig. 3. Scanning electronmicrograph showing the urothelium of diabetic mouse colonised by $S$. marcescens $\mathrm{T}-5548 \mathrm{~h}$ after infection. Numerous bacteria adhere to urothelium $(\times 2000)$.

In the present study, we analysed the mechanisms involved in the increased susceptibility of the diabetic bladder to infection with $S$. marcescens so far as bladder epithelial cells are involved. Our studies have shown that of the six strains of $S$. marcescens tested, five showed greater adherence to the bladder epithelial cells of diabetic mice than to those of normal mice. These findings were confirmed by electronmicroscopy. However, this adherence was reduced by D-mannose (table IV). Moreover, S. marcescens strain T-55 grown in nutrient broth possessed numerous fine fimbriae of

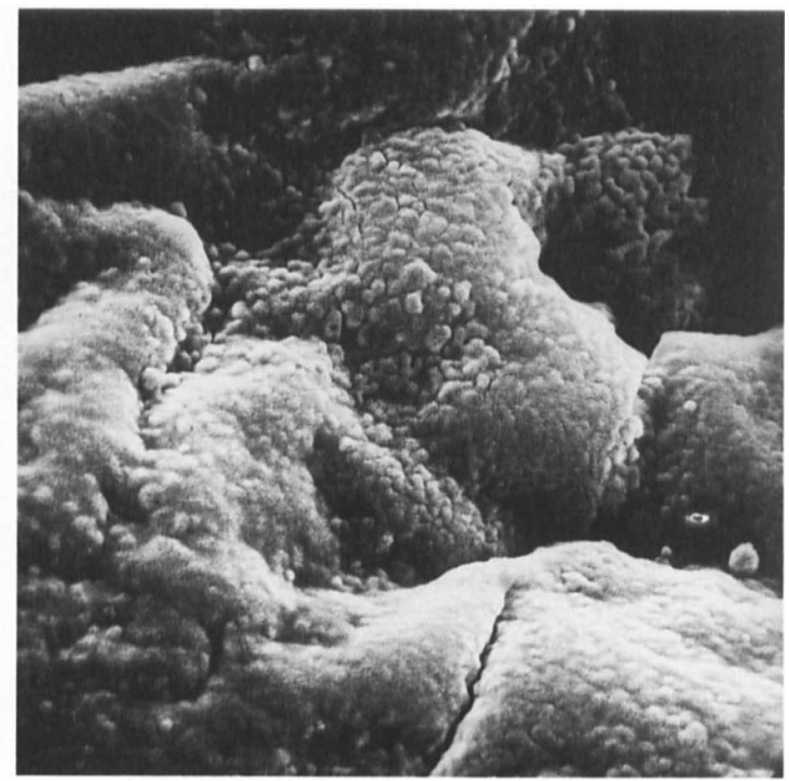

Fig. 5. Scanning electronmicrograph of the urothelium of normal mouse, $72 \mathrm{~h}$ after infection with $S$. marcescens $\mathrm{T}-55$. The nonwrinkled surface is filled with mucin-like substance. Bacteria adhering to urothelium are not seen $(\times 4000)$. 
different types. The clinical significance of the fimbriae of $S$. marcescens in urinary tract infection in man is not clear. Amako et al. ${ }^{8}$ reported that $S$. marcescens isolated from patients with respiratory and urinary tract infections possessed numerous fine filaments and agglutinated in human urine. The increased adherence of bacteria to bladder epithelial cells of diabetic mice may be attributed to the numerous mannose-sensitive fimbriae and this may facilitate the establishment of urinary tract infection in mice. These fimbriae may act as a colonisation factor. Moreover, this study suggests that alloxan may enhance the attachment of bacteria to bladder epithelial cells; we believe that the increased adhesive capacity results from the induced diabetes. However, it is necessary to determine whether alloxan has a direct or indirect effect on bacterial adherence. Ramphal et al. ${ }^{9}$ proposed that alteration of the cell surfaces or cell injury facilitates the opportunist adherence of $P$. aeruginosa. Davis $e t$ $a l .{ }^{10}$ suggested that the mannose-sensitive receptor on rat bladder epithelial cells consists of periodate- and lipase-sensitive compounds, possibly a glycolipid. This apparent difference in bacterial adherence between normal and diabetic mice may be due to the nature of

\section{References}

1. Obana Y, Nishino T, Tanino T. Enhanced susceptibility of diabetic mice to gram-negative organisms. Nihon Saikingaku Zasshi (Jpn J Bacteriol) 1987; 42: 653-661 (in Japanese).

2. Obana Y, Nishino T. The virulence of Enterobacter cloacae and Serratia marcescens in experimental bladder infection in diabetic mice. J Med Microbiol 1989; 30: 105-109

3. Obana $Y$, Nishino T, Tanino T. Therapeutic efficacy of $\beta$ lactam and aminoglycoside antibiotics on experimental pneumonia caused by Klebsiella pneumoniae B- 54 in diabetic mice. J Antibiotics 1985; 38: 941-947.

4. Obana $Y$, Nishino $T$, Tanino T. In-vitro and in-vivo activities of antimicrobial agents against Acinetobacter calcoaceticus. $J$ Antimicrob Chemother 1985; 15 : 441-448.

5. Hagberg L, Jodal U, Korhonen TK, Liden-Janson G, Lindberg U, Eden CS. Adhesion, hemagglutination, and virulence of Escherichia coli causing urinary tract infections. Infect Immun $1981 ; 31$ : 564-570.

6. Obana $Y$, Nishino $T$, Tanino $T$. The virulence of glucose nonfermentative organisms in experimental pyelonephritis in the host cell receptor. This may be a glycolipid that is involved in adherence. The host-cell receptor for the ligand of $S$. marcescens has not yet been identified. Therefore, it is necessary to investigate the host-cell receptor of diabetic mice for $S$. marcescens. The results of this study suggest that mannose-sensitive fimbriae mediate the adherence of $S$. marcescens to mouse bladder epithelial cells. Although adherence to the bladder wall is important for the initiation of infections, it is not the sole determinant of virulence. Urinary tract infections caused by $S$. marcescens are usually associated with an underlying disease. The presence of an in-dwelling catheter, which more or less disturbs the normal flow of urine, or other special underlying conditions have also been implicated. The susceptibility of diabetic mice to bladder infection may be due to a combination of increased adhesive capacity of bladder epithelial cells, low antibacterial activity of the urine ${ }^{2}$ and depression of host defences such as chemotactic and phagocytic activity of polymorphonuclear cells and macrophages. ${ }^{1,11,12}$ Further work is needed to determine fully the mechanisms involved in the susceptibility of the diabetic bladder to infection. mice. Kansenshogaku Zasshi (J Jpn Assoc Infect Dis) 1985; 59: $580-587$.

7. Iwahi T, Abe Y, Nakao M, Imada A, Tsuchiya K. Role of type 1 fimbriae in the pathogenesis of ascending urinary tract infection induced by Escherichia coli in mice. Infect Immun $1983 ; 39: 1307-1315$.

8. Amako K, Ohshima H, Yasunaka K, Kono K. Pili mediated agglutination of Serratia marcescens in human urine. Microbiol Immunol 1981; 25: 981-992.

9. Ramphal R, Small PM, Shands JW, Fischlschweiger W, Small PA. Adherence of Pseudomonas aeruginosa to tracheal cells injured by influenza infection or by endotracheal intubation. Infect Immun 1980; 27: 614-619.

10. Davis CP, Avots-Avotins AE, Fader RC. Evidence for a bladder cell glycolipid receptor for Escherichia coli and the effect of neuraminic acid and colominic acid on adherence. Infect Immun 1981 ; 34: 944-948.

11. Coil JA, Davis JH. Altered host response to experimental pyelonephritis in alloxan diabetic rats. J Surg Res 1967; 7 : 26-34.

12. Saiki O, Negoro S, Tsuyuguchi I, Yamamura Y. Depressed immunological defense mechanisms in mice with experimentally induced diabetes. Infect Immun 1980; 28: 127131. 